\title{
Evaluation of the response of cortisol, corticotropin and blood platelets kinetics after laparoscopic and open cholecystectomy ${ }^{1}$
}

\author{
Avaliação da resposta do cortisol, da corticotropina e da cinética das plaquetas após \\ colecistectomias laparoscópica e aberta
} \author{
Alex Augusto Silva \\ 1. Discipline of Digestive Surgery, Federal School of Medicine, FMTM. Uberaba, Minas Gerais - Brazil. \\ 2. Professor MD, PhD of Digestive Surgery - FMTM. Uberaba, Minas Gerais - Brazil. \\ 3. Medical student- FMTM. Uberaba, Minas Gerais - Brazil. \\ 4. Physician of Hematology Department- FMTM. Uberaba, Minas Gerais - Brazil. \\ 5. Assistant Professor of Digestive Surgery - FMTM. Uberaba, Minas Gerais - Brazil.
}

Eduardo Crema ${ }^{2}$, Elisangela Neto Ribeiro ${ }^{3}$, Ana Marcela Hial ${ }^{4}$, Juverson Terra Alves Júnior ${ }^{5}$, Ricardo Pastore ${ }^{5}$,

\begin{abstract}
Purpose: To compare the behavior of serum cortisol and ACTH levels and platelet kinetics after laparoscopic and open cholecystectomy. Methods: In this prospective study, 31 patients with symptomatic cholelithiasis submitted to elective cholecystectomy, 17 by the laparoscopic route and 14 by the open route, were compared. Peripheral blood samples were collected on admission of the patient, during anesthetic induction, and 2, 6, 12, 24 and 48 hours after the surgical incision. Platelets were counted in hematoxylin-eosin-stained specimens under a light microscope at 100X magnification. Cortisol and ACTH were measured by chemiluminescence. Results: Cortisol and ACTH levels showed a significant increase $(p<0.05)$ within the first hours after surgery compared to preoperative values. At 2 hours, a significantly higher cortisol concentration was observed in the laparoscopic group compared to the open surgery group ( $\mathrm{p}=0.0365)$. A return to basal levels during the later postoperative periods ( 24 and 48 hours) was only observed for ACTH, while serum cortisol continued to be elevated during the same period, being significantly higher in the open surgery group than in the laparoscopic group (p24 = 0.0248 and p48 = 0.032). Different platelet response curves were obtained for the two groups, but their levels were normal at all times studied. No significant difference ( $>>0.05$ ) between the post- and preoperative periods was observed for either group. Conclusion: A hormonal response was observed for both procedures studied, but the surgical stress was higher and longer lasting in open surgery compared to the laparoscopic approach. However, no significant variation in platelet kinetics in response to tissue injury was observed between the two procedures.
\end{abstract}

Key words: Hydrocortisone. Corticotropin. Blood Platelets. Cholecystectomy, Laparoscopic.

\section{RESUMO}

Objetivo: Comparar o comportamento dos níveis séricos de cortisol, ACTH e da cinética das plaquetas nas colecistectomias laparoscópica e aberta. Métodos: Esse estudo prospectivo compara 31 pacientes portadores de colelitíase sintomática que se submeteram a colecistectomia eletiva, sendo que 17 por via laparoscópica e 14 por via aberta. Amostras de sangue periférico foram colhidas na internação do paciente, na indução anestésica, às 2, 6, 12, 24 e 48 horas da incisão cirúrgica. A contagem de plaquetas foi realizada no microscópio óptico- aumento de 100X-pela coloração de Hematoxilina- eosina . As dosagens de cortisol e ACTH foram realizadas através da técnica de quimioluminescência. Resultados: Observou-se que as concentrações de cortisol e ACTH elevaram-se significativamente $(p<0.05)$ nas primeiras horas em relação aos valores do pré-operatório. Às 2 horas, houve elevação maior do nível de cortisol no grupo laparoscópico com diferença estatisticamente significante ( $\mathrm{p}=0,0365 ; \mathrm{p}<0.05$ ) em relação ao grupo aberto. Observou-se retorno a valores basais no pósoperatório tardio (24 e 48 horas) somente para o ACTH, enquanto que o nível sérico de cortisol manteve-se elevado nesse mesmo período, com valores maiores e estatisticamente significante ( $\mathrm{p} 24=0,0248$ e p48=0,0320;p<0.05) no grupo aberto em relação ao laparoscópico. As plaquetas apresentaram curvas de respostas diferentes entre os grupos, todavia mantiveram níveis normais em todos os momentos estudados. Não houve diferença estatística significante $(\mathrm{p}<0.05)$ entre os períodos pós e pré-operatórios em ambos os grupos. Conclusão: A resposta hormonal ocorre em ambos procedimentos estudados, porém o estresse cirúrgico é maior e mais duradouro na cirurgia aberta quando comparada à laparoscópica. Não obstante, a cinética das plaquetas não mostrou variação significativa em ambos procedimentos diante da injúria tecidual.

Descritores: Hidrocortisona. Corticotropina. Plaquetas. Colecistectomia laparoscópica. 


\section{Introduction}

Over the last few years, laparoscopic cholecystectomy has been increasingly applied as a method of choice for the treatment of patients with conditions such as cholelithiasis due to the current concern in minimizing surgical trauma through a smaller incision in the abdominal cavity, with a consequent reduced exposure ${ }^{1-3}$.

Laparoscopic cholecystectomy has been shown to attenuate endocrine-metabolic, immunological and inflammatory responses ${ }^{4-7}$. Consequently, this approach provides a better clinical outcome for the patient, including a reduction in postoperative pain, better ventilatory function, faster recovery and earlier discharge from the hospital compared to open cholecystectomy ${ }^{8-11}$.

Therefore, in the present study we evaluated changes in serum cortisol and ACTH levels in order to compare the hormonal response to tissue injury that occurs after laparoscopic and open cholecystectomy. In addition, platelet kinetics was determined during these procedures in view of the fact that these cells participate in the acute phase of the inflammatory response and also because of their fundamental role in spontaneous hemostasis ${ }^{12}$. We did not find any study in the literature evaluating the platelet response in these surgical procedures.

\section{Methods}

A prospective study was conducted on 31 patients with symptomatic cholelithiasis without complications, who underwent elective cholecystectomy at the Discipline of Digestive Tract Surgery of the Teaching Hospital, Federal School of Medicine. Patients presenting enzyme alterations or acute cholecystitis were excluded. The patients included in the study were divided into two groups: 17 patients were submitted to laparoscopic cholecystectomy and 14 patients were submitted to open cholecystectomy. The clinical characteristics of the patients including age, gender, weight and physical status are shown in Table 1 . There was no significant difference between the laparoscopic and open surgery groups.

TABLE 1 - Characteristics of the patients.

\begin{tabular}{lll}
\hline & $\begin{array}{l}\text { Laparoscopic group } \\
(\mathrm{n}=17)\end{array}$ & $\begin{array}{l}\text { Open group } \\
(\mathrm{n}=14)\end{array}$ \\
\hline Age & $45+/-14,82$ & $56+/-13,81$ \\
Extremes & $25-70$ & $31-75$ \\
Weight(Kg) & $70+/-13,40$ & $64,5+/-12,0$ \\
Male Gender & 1 & 7 \\
Female Gender & 13 & 10 \\
Physical Status & & \\
ASA I & 9 & 7 \\
ASA II & 5 & 10 \\
\hline
\end{tabular}

The patients were submitted to general anesthesia in order to minimize the influence of the procedure on the hormonal response. Blood samples were collected on admission of the patient, immediately before anesthesia, and 2, 6, 12, 24 and 48 hours after the surgical incision (A2,
A6, A12, A24, A48 respectively) Platelets were counted in hematoxylin-eosin stained specimens under a light microscope at $100 \mathrm{X}$ magnification. Cortisol and ACTH were measured by chemiluminescence. Statistical analysis was performed using the Mann-Whitney $U$ test, with differences being considered statistically significant when $\mathrm{p}<0.05$.

\section{Results}

\section{Response of cortisol and ACTH}

A significant increase in plasma cortisol (Figure 1) was observed in the laparoscopic group 2 hours after the surgical incision compared to preoperative values $(\mathrm{p}=0.0365)$. The open surgery group presented a maximum cortisol peak after 6 hours, whereas in the laparoscopic group the maximum peak was reached 12 hours after the surgical incision. A significant decrease in plasma cortisol concentration was observed in the laparoscopic group compared to the open surgery group 24 and 48 hours after surgery $(p=0.0248$ and $\mathrm{p}=0.032$, respectively). However, the values observed during these periods were higher than the preoperative levels.

Regarding ACTH (Figure 2), the laparoscopic group presented an expressive increase 2 hours after surgery, followed by a rapid decline at 12 hours. The open surgery group showed a maximum peak 6 hours after surgery, with a decrease in these values close to preoperative levels being only observed 24 hours after the surgical incision. Comparison of ACTH levels with preoperative values only demonstrated a significant difference $(\mathrm{p}<0.05)$ at 2 and 6 hours in the two groups. No significant difference in ACTH levels was observed between groups at any time point studied.

\section{Blood platelets kinetics}

The absolute platelet counts (Figure 3) were normal $\left(200,000-400,000 / \mathrm{mm}^{3}\right)$ or close to normal in the two groups at all time points studied, with no significant $(\mathrm{p}<0.05)$ difference between post- and preoperative values. Also, no significant difference $(\mathrm{p}<0.05)$ in platelet count was observed between the laparoscopic and open surgery groups. The mean absolute number of platelets ranged from 189,750 to $214,750 / \mathrm{mm}^{3}$ in the laparoscopic group, and from 198,000 to $227,000 / \mathrm{mm}^{3}$ in the open surgery group.

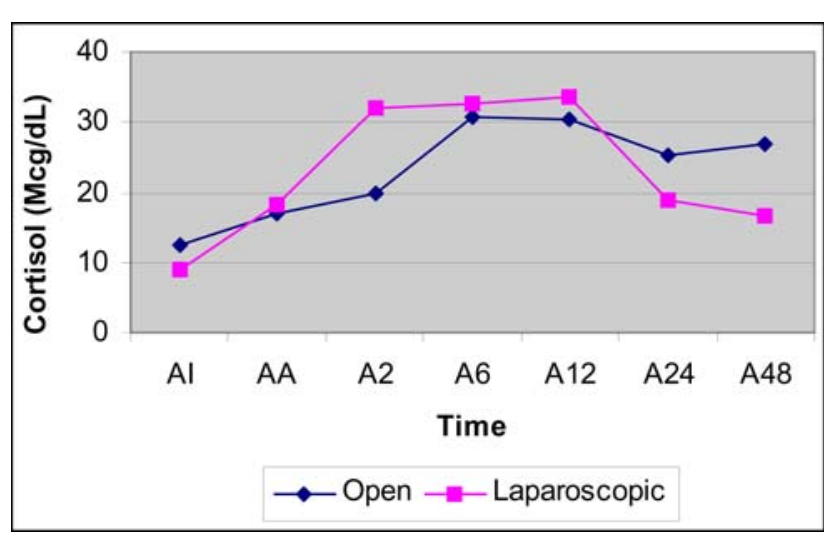

FIGURE 1 - Mean plasma cortisol concentration. 


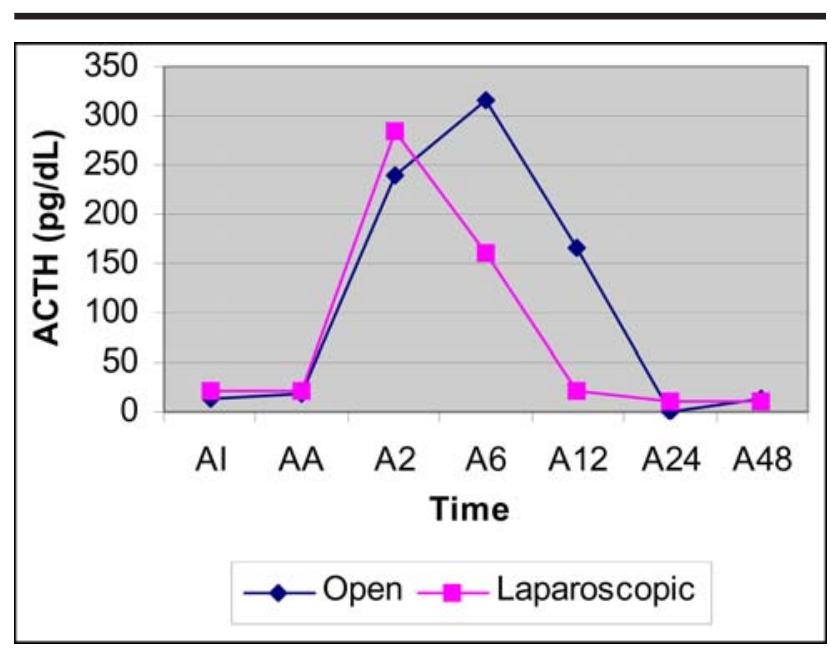

FIGURE 2 - Mean plasma ACTH concentration.

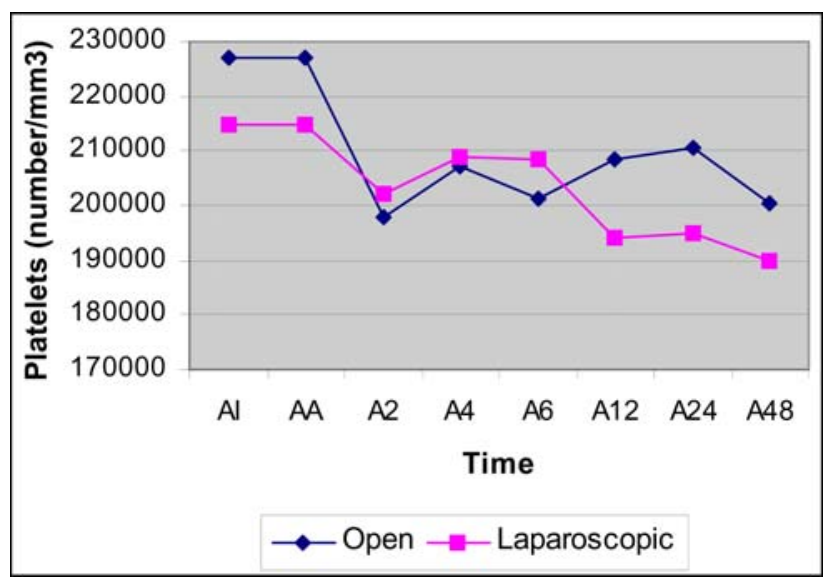

FIGURE 3 - Platelets kinetics.

\section{Discussion}

The objective of the present study was to determine the alterations in cortisol, ACTH and platelet number in response to surgical stress provoked by laparoscopic cholecystectomy compared to open cholecystectomy. Both procedures caused changes in the hormonal response ${ }^{13,14}$. A significant increase in plasma cortisol and ACTH was observed during the intraoperative period and in the first hours after surgery, an expected response to surgical stress also reported in the literature ${ }^{13-15}$. A significant difference in cortisol levels was observed between the laparoscopic and open surgery groups 2, 24 and 48 hours after surgery ${ }^{16}$, with the increase being higher in the laparoscopic group at 2 hours, probably because of the presence of pneumoperitoneum ${ }^{17}$. Similar to other reports ${ }^{17,18}$, an earlier increase in cortisol levels and a faster return to preoperative values were observed for the laparoscopic procedure. In open cholecystectomy, however, cortisol levels continued to be elevated 24 and 48 hours after surgery compared to baseline, indicating a longer lasting response to surgical stress as previously described ${ }^{19,20}$.

In contrast, no significant difference was observed between the groups studied regarding ACTH. Similar the cortisol response, an earlier increase in ACTH and a faster return to preoperative values were observed during laparoscopic cholecystectomy ${ }^{21}$. However, in contrast to cortisol, ACTH returned to basal levels during the postoperative period in both groups, as also demonstrated in other studies ${ }^{14,17}$.

Platelets play an important role in spontaneous hemostasis, interrupting in a natural manner the hemorrhage resulting from the traumatic rupture of blood vessels. In addition, these cells act on the acute phase of the inflammatory response that occurs in response to tissue injury, releasing vasoactive amines (histamine and serotonin) that are chemical mediators of inflammation ${ }^{12}$. However, we observed no significant difference in the absolute number of these cells in response to the surgical procedure in either group. Other studies have reported that in situations of stress, such as that caused by these surgical procedures, initially only increased volume platelets are mobilized, while an increase in the absolute number of circulating cells is observed after 1 or 2 days $^{22,23}$.

\section{Conclusion}

A hormonal response to cholecystectomy occurred in both procedures studied, but the surgical stress was higher and longer lasting in open surgery compared to the laparoscopic approach. However, no significant variation in platelet kinetics in response to tissue injury was observed between the two procedures.

\section{References}

1. Schippers E, Ottinger AP, Anurov M, Polivoda M, Schumpelick V. Laparoscopic cholecystectomy. A minor abdominal trauma? World J Surg. 1993; 17: 539-43.

2. Griffith JP, Everitt NJ, Lancaster F, et al. Influence of laparoscopic and conventional cholecystectomy upon cell-mediated immunity. Br J. 1995; 82: 677-80.

3. Wickham JEA. Minimally invasive surgery. Br J Surg. 1990; 22: 721-22.

4. Mealy K, Gallagher H, Barry M, Lennon F, Traynor O, Hyland J. Physiological and metabolic responses to open and laparoscopic cholecystectomy. Br J Surg. 1992; 79:1061-4.

5. Jakeways MSR, Mitchell V, Hashim IA, Chadwick SJD, Shenkin A, Green CJ, Carli F. Metabolic and inflammatory responses after open or laparoscopic cholecystectomy. Br J Surg. 1994; 81: 127-31.

6. Crema E. Comparative study of surgical stress determined by hormone and cytokine plasma levels in open and laparoscopy cholecystectomy. Dig Surg. 1999; 105: 37-40

7. Crema E, Werneck AM, Cruvinel LAF, Crema MD, Rodrigues JrV, Silva AA. Analyse des cytokines proinflammatoires (IL-1 et TNF-a) et anti-inflammatoires (IL4 et IL-10) chez les patients soumis a la cholécystectomie ouverte et coelioscopique. J Coeliochir. 2003; 48: 63-7.

8. Coelho JCU, De Araujo RPM, Marchesini JB, Coelho ICM, Araujo LRR. Pulmonary function after cholecystectomy performed through Kocher's incision, a mini incision and laparoscopy. World J Surg. 1993; 17: 544-6.

9. Delaunay L, Bonnet F, Cherqui D, et al. Laparoscopic 
cholecystectomy minimally impairs postoperative cardiorespiratory and muscle perfomance. Br J Surg. 1995; 82:373-6.

10. Grace PA, Quereshi A, Coleman J, et al. Reduced postoperative hospitalization after laparoscopic cholecystectomy. Br J Surg.1991; 78: 160-2.

11. Hendolin HI, Paakonin ME, Alhava EM, et al. Laparoscopic or open cholecystectomy: a prospective randomised trial to compare postoperative pain, pulmonary function, and stress response. Eur J Surg. 2000; 166(5): 394-9.

12. Robbins. Patologia estrutural e funcional. 5ed. São Paulo: Editora Guanabara Koogan; 1996.

13. Bellón JM, Manzano L, Larrad A, Honduvilla GN, Bujan J, Alvares-Mon M. Endocrine and immune response to injury after open and laparoscopic cholecystectomy. Int Surg. 1995; 83(1): 24-7.

14. Glaser F, Sannwald GA, Burh HJ, Kuntz C, Mayer H, Klee F, Herfarth C. General stress response to conventional and laparoscopic cholecystectomy. Ann Surg. 1995; 221:372-80.

15. Crema E, Bisiontto FMB, Abud TMV, Alves Neto J. Resposta endócrina em colecistectomia: Estudo comparativo entre a técnica cirúrgica convencional e a videolaparoscópica. Rev Bras Anestesiol. 1996; 46: 317-22.

16. Mr Ksic M, Feher I, Mir Kovic M. Hormonal and hyperglycemic response in laparoscopic and open cholecystectomy. Magy Seb. 2002; 55(2): 81-5.
17. Yoshida T, Kobayashi E, Suminaga Y, Yamauchi H, Kai T, Toyama N, Kiyozaki H, et al. Hormone-cytokine response. Pneumoperitoneum vs abdominal wall-lifting in laparoscopic cholecystectomy. Surg Edosc. 1997; 11(9): 907-10.

18. Deuss U, Dietrich J, Kauleen D, Frey K, Spangenberger W, Allolio B, Matuszczak M., et al. The stress response to laparoscopic cholecystectomy: investigation of endocrine parameter. Endoscopy. 1994; 26: 235-8.

19. Bickel U, Wiegand-Löhnert C, Fleischmann JW, et al. Different modulation of the perioperative stress hormone response under neurolept-anaesthesia or enflurane for cholecystectomy. Horm Metabol Res. 1991; 23: $178-84$.

20. Schauer PH, Sirinek KR. The laparoscopic approach reduces the endocrine response to elective cholecystectomy. Am Surg.. 1995; 61:106-11.

21. Crema E, Macedo AM, Brucco A, Bisiotto FMB, Chaves Neto HP. Endocrine response in cholecystectomy: comparative study between conventional and videolaproscopy. Int Proc. 1996; 691-4.

22. Martin JF, Trowbridge EA., Salmon GL, Slater DN. The relationship between plaquetet and megakaryocyte volumes. Thromb Res. 1982; 28: 447.

23. Corash L, Chen HY, Levin J, et al. Regulation of thrombopoiesis: Effect of the degree of thrombocytopenia on megakaryocite ploidy and plaquetet volume. Blood. 1987; 70: 177.

\section{Correspondence:}

Eduardo Crema

Departamento de Cirurgia do Aparelho Digestivo

Av. Getúlio Guaritá, s/n.

38025-450 Uberaba-MG Brazil

eduardocremafmtm@mednet.com.br
Conflict of interest: none Financial source: none

Received: April 05, 2005

Review: May 10, 2005

Accepted: June 14, 2005

\section{How to cite this article:}

Crema E, Ribeiro EN, Hial AM, Alves Júnior JT, Pastore R, Silva AA. Evaluation of the response of cortisol, corticotropin and blood platelets kinetics after laparoscopic and open cholecystectomy. Acta Cir Bras. [serial on the Internet] 2005 SeptOct;20(5). Available from URL: http://www.scielo.br/acb

*Color figures available from $\underline{\text { http://www.scielo.br/acb }}$ 